\title{
HAEMATO-BIOCHEMICAL PROFILE AND MILK LEUKOCYTE COUNT IN SUBCLINICAL AND CLINICAL MASTITIS AFFECTED CROSSBRED CATTLE
}

\author{
Sarvesha $K^{1}$, Satyanarayana $\mathrm{M} \mathrm{L}^{1}$, Narayanaswamy $\mathrm{H} \mathrm{D}^{1}$, Rao $\mathrm{S}^{1}$, Yathiraj $\mathrm{S}^{2}$, Isloor $\mathrm{S}^{3}$, \\ Mukartal S $\mathrm{Y}^{3}$, Singh $\mathrm{S} \mathrm{V}^{4, *}$ and Anuradha $\mathrm{M} \mathrm{E}^{5}$ \\ ${ }^{1}$ Department of Pathology, Veterinary College, Hebbal, KVAFSU, Bangaluru- 560024 \\ ${ }^{2}$ Dean, Veterinary College, Hebbal, KVAFSU, Bangaluru 560024 \\ ${ }^{3}$ Department of Veterinary Microbiology, Veterinary College, Hebbal, KVAFSU, Bangaluru-560 024. \\ ${ }^{4}$ Principal Scientist, Division of Animal Health, Central Institute for Research on Goats (CIRG), Makhdoom, PO-Farah, Mathura-281122, Uttar Pradesh, India \\ ${ }^{5}$ Research Associate, ICAR NAE project, Veterinary College, Bengaluru, 560024
}

Received - September 06, 2016; Revision - November 06, 2016; Accepted - January 22, 2017

Available Online - February 10, 2017

DOI: http://dx.doi.org/10.18006/2017.5(1).001.006

\begin{abstract}
KEYWORDS
Mastitis

TLC

Lymphocytes

Neutrophils

DLC

California Mastitis Test (CMT)

ABSTRACT

The study was conducted to determine the effect of subclinical mastitis (SCM) and clinical mastitis (CM) on haemato-biochemical parameters and milk leukocyte count of crossbred cattle. Milk and blood samples were collected from 20 healthy, 223 SCM and 47 CM affected animals from Kolar and Chikkaballapur districts of Karnataka state, India. The SCM were diagnosed by California Mastitis Test (CMT) and electrical conductivity (EC) of milk. Blood and milk of mastitis infected crossbred cattle were analyzed for haemato-biochemical parameters and milk leukocyte count. Haematology showed significant increase in TLC in crossbred cows affected with mastitis. Significantly $(\mathrm{P}<0.05)$ lower average values of TEC, $\mathrm{Hb}$ and PCV were observed in SCM infected animals, however no significant change were observed in values of CM infected than healthy animals. Differential leucocytic count (DLC) revealed higher granulocytes and lymphopenia in mastitis infected animals. Biochemical estimation revealed significantly $(\mathrm{P}<0.05)$ higher average values of $\mathrm{Ca}, \mathrm{P}, \mathrm{Na}, \mathrm{Cl}$, and $\mathrm{K}$ in mastitis infected compared with healthy animals however, no significant $(\mathrm{P}>0.05)$ change was observed in $\mathrm{Mg}$ and ALT levels. AST and TP values were significantly increased in SCM infected compared to healthy animals however, no significant change were observed in $\mathrm{CM}$ infected animals. Macrophage and
\end{abstract}

\section{* Corresponding author}

E-mail: shoorvir.singh@gmail.com (Singh S V)

Peer review under responsibility of Journal of Experimental Biology and Agricultural Sciences.

Production and Hosting by Horizon Publisher India [HPI] (http://www.horizonpublisherindia.in/).

All rights reserved.
All the article published by Journal of Experimental Biology and Agricultural Sciences is licensed under a Creative Commons Attribution-NonCommercial 4.0 International License Based on a work at www.jebas.org.

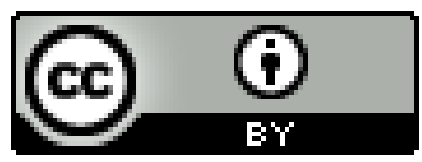


lymphocyte count showed significant decrease, however the total leukocyte and neutrophil count in milk were significantly increased in mastitis affected animals. The changes in haematobiochemical parameters and milk leukocyte count are important indicators of the physiological or pathological state (mastitis) of the animal.

\section{Introduction}

Mastitis remains a serious concern to dairy farmers till date. Mastitis is an inflammation of the mammary gland of dairy cattle associated with physical, bacteriological and pathological alterations in milk and tissue of mammary gland. Blood \& Radostits (1989) defined mastitis as a disease characterized by the presence of significantly increased leucocytes content in the milk from affected gland.

High yielding milch animals, especially crossbred and exotic breeds are more prone for mastitis with infection being higher in late lactation in comparison to the first. Crossbreeding of cattle for better milk production is also a primary cause for mastitis due to changes in position, size and rapid milk excretion from mammary gland causing stressful condition leading to udder infection (Gibbons et al., 1970).

Subclinical and clinical forms of mastitis occur in dairy cattle where the subclinical mastitis usually leads to the clinical form even though the association between both types is not clear in larger group of animals (Rolands \& Booth, 1988). Subclinical mastitis is a neglected disease by dairy farmers even though it causes a huge economic loss to the dairy industry. Disruption of the blood-milk barrier in addition to decreased production and secretion from udder epithelial cells which causes a change in milk composition in mastitic animals. The evaluation of the haemato-biochemical changes and alterations in milk leukocyte count of mastitis affected crossbred cows was undertaken in the present study.

\section{Materials and Methods}

Blood samples were collected from jugular vein of 20 healthy, 223 SCM and 47 CM affected crossbred cattle from Kolar and Chikkaballapur districts of Karnataka state, India in heparinised mineral free (15- 20ml) vials and disodium EDTA $(2-3 \mathrm{ml})$ vials. Blood samples were transported to the laboratory within one hour in a thermo flask with ice $\&$ then fresh blood was analyzed for $\mathrm{Hb}, \mathrm{PCV}$, TEC, TLC, ESR and DLC by using fully automated hematology analyzer (Mindray, BC1800). The serum separated from blood was analyzed for ALT, AST, $\mathrm{Ca}, \mathrm{Cl}, \mathrm{K}, \mathrm{Mg}, \mathrm{Na}, \mathrm{P}$ and TP by using fully automated biochemical analyzer (Thermo scientific KONELAB 20).

The milk samples collected were subjected for California Mastitis test (CMT), Somatic cell count (SCC) and electrical conductivity (EC) measurement. EC was determined by using Milk checker (Eisai Co. Ltd. and Oriental instruments Ltd., Tokyo. Japan) and a value more than $6.5 \mathrm{mS} / \mathrm{cm}$ were considered as positive for SCM (Swarup et al., 1989). Milk samples for differential leukocyte count and somatic cell count were collected under aseptic conditions in sterile containers. Milk total somatic cell and differential leukocyte count were estimated according to general principle of Prescott and Breed method as detailed by Schalm et al. (1971) and a value $>5.00$ Lakhs/ml of milk was taken as criteria to declare the milk or animal as subclinically mastitic or infected. The data obtained from the study was analyzed by one way analysis of variance (ANOVA) test using Graph Pad Prism version 5 for windows.

\section{Results and Discussion}

Haematology of animals revealed significantly $(\mathrm{P}<0.05)$ higher average values of ESR and TLC in mastitis infected than healthy animals. Significantly $(\mathrm{P}<0.05)$ lower average values of TEC, Hb and PCV were observed in SCM infected animals, however no significant change were observed in values of CM infected than healthy animals. DLC revealed higher granulocytes and lymphopenia in mastitis infected animals (Table 1). Biochemical estimation revealed significantly $(\mathrm{P}<0.05)$ higher average values of $\mathrm{Ca}, \mathrm{P}, \mathrm{Na}, \mathrm{Cl}$, and $\mathrm{K}$ in mastitis infected compared with healthy animals however, no significant $(\mathrm{P}>0.05)$ change was observed in $\mathrm{Mg}$ and ALT levels. AST and TP values were significantly increased in SCM infected compared to healthy animals however, no significant change were observed in CM infected animals (Table 2). The total milk leukocytes and neutrophils were significantly higher, while lymphocytes and macrophages population were significantly lower in mastitis infected animals (Table 3). Significant increase in EC of milk from SCM and CM infected animals were observed in comparison to healthy animals.

$\mathrm{Hb}$, TEC and PCV level of SCM cows showed significant decrease in comparison to healthy animals. These observations are in accordance with Zaki et al. (2010) those who recorded significant reduction in $\mathrm{RBC}, \mathrm{Hb}$ and $\mathrm{PCV}$ values leading to anaemia in animals affected with mastitis. No significant changes were observed in $\mathrm{Hb}$ and TEC level of $\mathrm{CM}$ affected animals as opposed to healthy cows. No significant trends in PCV and $\mathrm{Hb}$ in mastitic cases were observed by Sischo et al. (1997) which is in line with the findings of this study. 
Table 1 Haematological parameters of control and mastitic crossbred cows.

\begin{tabular}{|ccccc|}
\hline Sl. No. & Parameter & Control $(\mathbf{n}=\mathbf{2 0})$ & \multicolumn{2}{c|}{ Mastitis } \\
& & & Sub clinical $(\mathbf{n}=\mathbf{2 2 3})$ & Clinical $(\mathbf{n}=\mathbf{4 7})$ \\
\hline $\mathbf{1}$ & $\mathrm{Hb}$ g/Dl & $10.50 \pm 0.29^{\mathrm{a}}$ & $9.03 \pm 0.01^{\mathrm{b}}$ & $9.80 \pm 0.24^{\mathrm{a}}$ \\
\hline $\mathbf{2}$ & $\mathrm{PCV} \%$ & $31.07 \pm 0.44^{\mathrm{a}}$ & $28.05 \pm 0.16^{\mathrm{b}}$ & $27.70 \pm 0.33^{\mathrm{b}}$ \\
\hline $\mathbf{3}$ & $\mathrm{TEC} \times 10^{6} / \mu \mathrm{L}$ & $7.22 \pm 0.17^{\mathrm{a}}$ & $6.91 \pm 0.04^{\mathrm{b}}$ & $7.05 \pm 0.08^{\mathrm{ab}}$ \\
\hline $\mathbf{4}$ & TLC $\times 10^{3} / \mu \mathrm{L}$ & $6.86 \pm 0.22^{\mathrm{a}}$ & $10.13 \pm 0.11^{\mathrm{b}}$ & $11.37 \pm 0.22^{\mathrm{c}}$ \\
\hline $\mathbf{5}$ & Granulocyte $(\%)$ & $35.74 \pm 0.77^{\mathrm{a}}$ & $65.16 \pm 0.21^{\mathrm{b}}$ & $70.64 \pm 0.53^{\mathrm{c}}$ \\
\hline $\mathbf{6}$ & Lymphocyte $(\%)$ & $60.52 \pm 0.65^{\mathrm{a}}$ & $30.72 \pm 0.24^{\mathrm{b}}$ & $25.61 \pm 0.59^{\mathrm{c}}$ \\
\hline $\mathbf{7}$ & Monocyte $(\%)$ & $3.75 \pm 0.42$ & $4.12 \pm 0.12$ & $3.75 \pm 0.27$ \\
\hline $\mathbf{8}$ & ESR mm/2hrs & $1.15 \pm 0.02^{\mathrm{a}}$ & $1.97 \pm 0.02^{\mathrm{b}}$ & $1.16 \pm 0.01^{\mathrm{a}}$ \\
\hline
\end{tabular}

Mean \pm SE values given for each treatments, Means marked with different letters are significantly differ $(\mathrm{P}<0.05)$ in a row.

Table 2 Biochemical parameters of control and crossbred cows.

\begin{tabular}{|ccccc|}
\hline Sl. No. & Parameter & Control $(\mathbf{n}=\mathbf{2 0})$ & \multicolumn{2}{c|}{ Mastitis } \\
& & & Sub clinical $(\mathbf{n}=\mathbf{2 2 3})$ & Clinical $(\mathbf{n}=\mathbf{4 7})$ \\
\hline $\mathbf{1}$ & $\mathrm{ALT} \mathrm{U} / \mathrm{L}$ & $10.02 \pm 0.37^{\mathrm{a}}$ & $10.11 \pm 0.21^{\mathrm{a}}$ & $10.03 \pm 0.23^{\mathrm{a}}$ \\
\hline $\mathbf{2}$ & $\mathrm{AST} \mathrm{U} / \mathrm{L}$ & $75.41 \pm 2.28^{\mathrm{a}}$ & $120.29 \pm 1.08^{\mathrm{b}}$ & $84.73 \pm 1.65^{\mathrm{a}}$ \\
\hline $\mathbf{3}$ & $\mathrm{TP} \mathrm{g} / \mathrm{dL}$ & $7.22 \pm 0.14^{\mathrm{a}}$ & $7.80 \pm 0.03^{\mathrm{b}}$ & $7.45 \pm 0.07^{\mathrm{a}}$ \\
\hline $\mathbf{4}$ & $\mathrm{Ca} \mathrm{mg/dL}$ & $9.37 \pm 0.25^{\mathrm{a}}$ & $13.04 \pm 0.08^{\mathrm{b}}$ & $12.90 \pm 0.22^{\mathrm{b}}$ \\
\hline $\mathbf{5}$ & $\mathrm{P} \mathrm{mg/dL}$ & $6.49 \pm 0.12^{\mathrm{a}}$ & $4.85 \pm 0.04^{\mathrm{b}}$ & $5.12 \pm 0.08^{\mathrm{c}}$ \\
\hline $\mathbf{6}$ & $\mathrm{Mg} \mathrm{mg} / \mathrm{dL}$ & $2.18 \pm 0.11$ & $2.26 \pm 0.03$ & $2.23 \pm 0.06$ \\
\hline $\mathbf{7}$ & $\mathrm{Cl} \mathrm{mEq} / \mathrm{L}$ & $99.20 \pm 1.30^{\mathrm{a}}$ & $88.62 \pm 0.32^{\mathrm{b}}$ & $90.04 \pm 0.79^{\mathrm{b}}$ \\
\hline $\mathbf{8}$ & $\mathrm{Na} \mathrm{mEq} / \mathrm{L}$ & $139.68 \pm 0.73^{\mathrm{a}}$ & $152.41 \pm 0.39^{\mathrm{b}}$ & $154.20 \pm 0.89^{\mathrm{b}}$ \\
\hline $\mathbf{9}$ & $\mathrm{K} \mathrm{mEq} / \mathrm{L}$ & $4.14 \pm 0.10^{\mathrm{a}}$ & $5.00 \pm 0.03^{\mathrm{b}}$ & $5.21 \pm 0.04^{\mathrm{c}}$ \\
\hline
\end{tabular}

Mean \pm SE values given for each treatments, Means marked with different letters are significantly differ $(\mathrm{P}<0.05)$ in a row.

Higher leukocyte and granulocyte count was recorded in the present study in clinical as well as subclinical mastitis affected animals. However lymphocyte count was observed to be significantly lower in mastitic cases. Zaki et al. (2008) and Khan et al. (1997) reported an increase in TLC in affected animals along with a higher monocyte, neutrophil and eosinophil count. The ESR of SCM infected animals was found to be higher than healthy animal however, no significant (P> 0.05) change was observed in CM affected animals. These findings are in agreement with Cebra et al. (1996); Zaki et al. (2008) which could be due to persistent infection noticed in SCM.

Significant increase in total protein (TP) level was observed in SCM cases as compared to healthy animals, however a non- significant rise was observed in CM infected animals. Higher levels of globulin and total protein was reported by Dwivedi et al. (2004) in serum of mastitic cows. However, reduced TP values in mastitic cases were observed by Zaki et al. (2008). This may be attributed to the decreased albumin levels after the immune response to the udder infection (Singh, 2000). Serum calcium level of the SCM and CM infected animals were significantly $(\mathrm{P}<0.05)$ higher than the healthy animals which is attributed to the reduced milk production in affected animals which causes decreased Ca excretion in milk (Wegner \& Stull, 1978). Singh et al. (2014) reported higher plasma levels of Ca in mastitis affected buffaloes which is similar to our findings. But in contrast to the present study Zaki et al. (2010) observed a reduction in the $\mathrm{Ca}$ values in the infected animals.

Table 3 Values of milk EC, SCC and DLC of control and mastitic crossbred cows.

\begin{tabular}{|ccccc|}
\hline SI. No. & Parameter & Control $(\mathbf{n}=\mathbf{2 0})$ & \multicolumn{2}{c|}{ Mastitis } \\
\hline $\mathbf{1}$ & & & Sub clinical $(\mathbf{n}=\mathbf{2 2 3})$ & Clinical $(\mathbf{n}=\mathbf{4 7})$ \\
\hline $\mathbf{2}$ & EC $\mathrm{mS} / \mathrm{cm}$ & $4.77 \pm 0.15^{\mathrm{a}}$ & $9.99 \pm 0.15^{\mathrm{b}}$ & $17.20 \pm 0.28^{\mathrm{c}}$ \\
\hline $\mathbf{3}$ & SCC Lakhs/mL & $1.89 \pm 0.10^{\mathrm{a}}$ & $7.76 \pm 0.09^{\mathrm{b}}$ & $14.96 \pm 0.27^{\mathrm{c}}$ \\
\hline $\mathbf{4}$ & NEUTROPHIL \% & $5.03 \pm 0.19^{\mathrm{a}}$ & $43.24 \pm 0.14^{\mathrm{b}}$ & $64.24 \pm 0.45^{\mathrm{c}}$ \\
\hline $\mathbf{5}$ & MACROPHAGE \% & $76.39 \pm 0.27^{\mathrm{a}}$ & $28.12 \pm 0.12^{\mathrm{b}}$ & $11.04 \pm 0.08^{\mathrm{c}}$ \\
\hline $\mathbf{6}$ & LYMPHOCYTE \% & $16.15 \pm 0.19^{\mathrm{a}}$ & $17.62 \pm 0.11^{\mathrm{b}}$ & $14.77 \pm 0.26^{\mathrm{c}}$ \\
\hline
\end{tabular}

Mean \pm SE values given for each treatments, Means marked with different letters are significantly differ $(\mathrm{P}<0.05)$ in a row. 


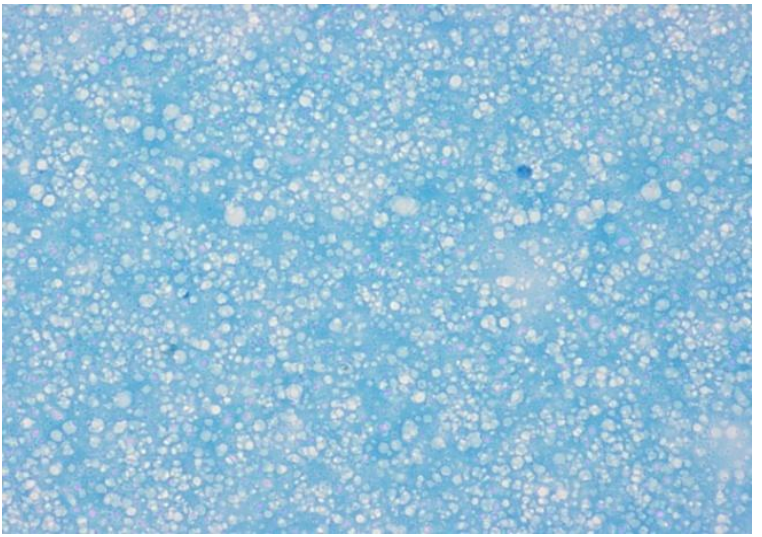

Figure 1 Microscopically milk showing occasional inflammatory cells in Newman's stain X 200.

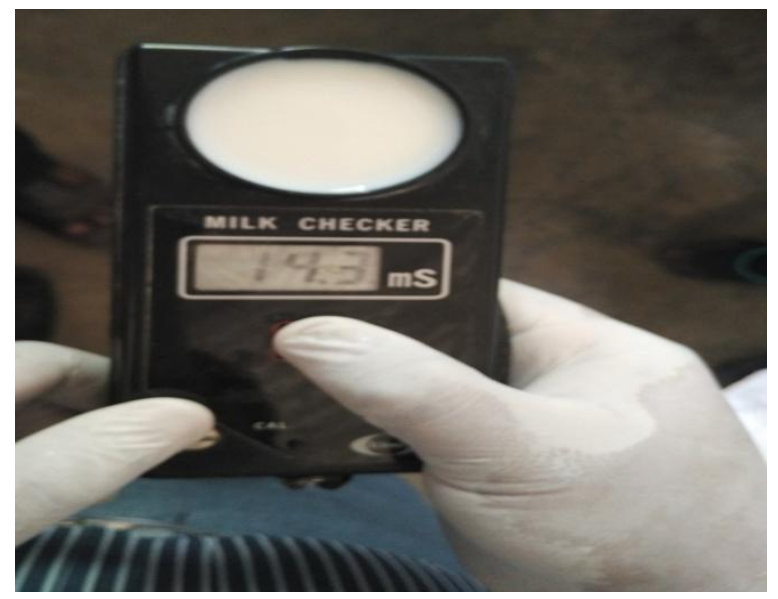

Figure 3 Detection of mastitis by EC test using milk checker instrument.

Average value of phosphorous of the healthy animals were significantly $(\mathrm{P}<0.05)$ higher than the SCM and CM infected animals which could be attributed to its higher secretion in milk, due to injury to the udder wall resulting in increased loss in milk which is in accordance with the observation of Dwivedi et al. (2004) and Siddiqe et al. (2015).

In the present study no significant change in magnesium levels were recorded in mastitis affected animals which was in agreement with the findings of Dwivedi et al. (2004) and Yildiz \& Kaygusuzolu (2005). However, higher levels in serum $\mathrm{Mg}$ of buffaloes suffering from acute mastitis were reported by Singh (1999) and decreased serum Mg levels were recorded by Siddiqe et al. (2015).

Sodium, chloride and Potassium levels of the SCM and CM infected animals were significantly $(\mathrm{P}<0.05)$ higher than the healthy animals. An increased level of sodium and potassium in serum of mastitic cases were observed which was in line with the findings of Atroshi et al. (1996). This was attributed

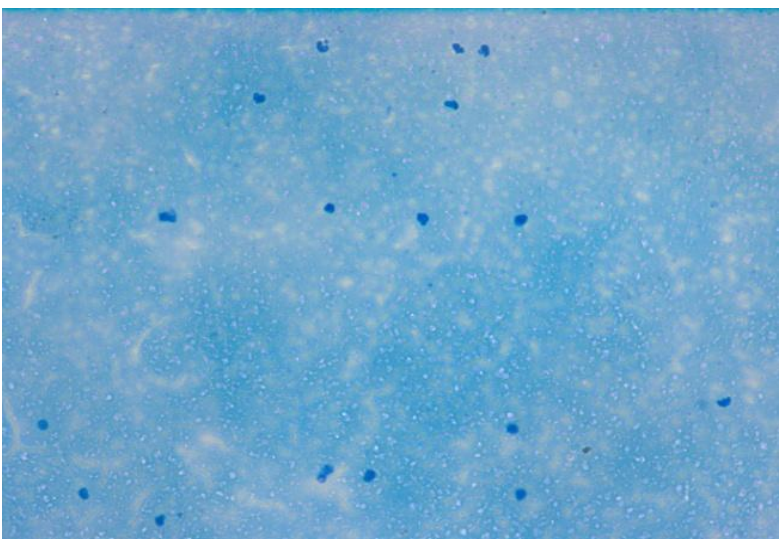

Figure 2 Microscopically mastitis infected milk showing abundant inflammatory cells in Newman's stain X 200

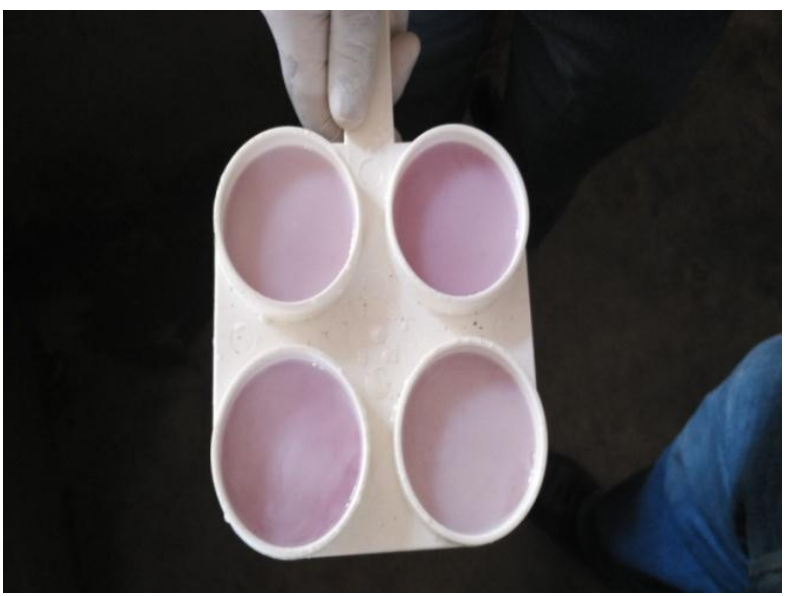

Figure 4 Detection of SCM by CMT test kit.

to the reduced milk yield during mastitis which elevates the level of sodium, potassium and chloride in blood due to minimal loss from the mastitis affected animal. Increased levels of plasma $\mathrm{K}$ in buffaloes suffering from mastitis was also reported by Singh (1999). The highly significant increases detected in AST values of SCM are in line with the reports of Bayumi et al. (2005) and Chandrasekaran et al. (2015) which could be due to stressful conditions.

The total milk leukocytes (Figure 1 \& 2) and granulocytes were significantly higher, while lymphocytes and macrophages population were significantly lower in mastitis infected animals indicating mammary gland infection. One of the most ideal biomarkers in mastitis is milk leukocyte count. In the present study, a higher level of milk leukocytes is indicative of the immune response caused by the microorganisms in the mastitis affected mammary gland (Djabri et al., 2002; Gargouri et al., 2008). These results are in line with the findings of Hussain et al., 2012 and Hussain et al., 2013. The colonization of mammary glands by pathogenic micro-organisms results in 
a series of events which leads to major alterations of milk compositions secreted from cells. Therefore CMT (Figure 4) is a suitable measure for use on large scale monitoring programs.

Significant increase in EC of milk from SCM and CM (Figure 3) infected animals were observed compared to healthy animals. This is in accordance with the reports of Sripad et al. (2013). The increase in EC milk of mastitis animals could be due to elevated levels of ions such as sodium, potassium, calcium and chloride during mammary gland inflammation.

In conclusion, the changes in haemato-biochemical parameters and milk leukocyte count can be used as important indicators of the physiological or pathological state (mastitis) of the animal .In addition, we conclude that CMT, EC and SCC is ideal for early detection of subclinically infected quarters and aids in the selection of dairy animals for either segregation or therapy.

\section{Acknowledgements}

Authors of the manuscript thank and acknowledge ICAR NAE Project entitled: "Animal Disease Registry and Tissue Bank" Veterinary College, Hebbal, Bengaluru-24 for financial support and also authors of respective Universities/Institutes.

\section{Conflict of interest}

Authors would hereby like to declare that there is no conflict of interests that could possibly arise.

\section{References}

Atroshi F, Parantainen J, Sankari S, Jarvinen M, Lindberg LA, Saloniemi H (1996) Changes in inflammation related blood constituents of mastitic cows. Veterinary Resarch 27: 125-132.

Bayumi FS, Zaki MS, Nasr SN, Gomaa HR (2005) Some microbiological studies on the goats suffering from subclinical mastitis. Veterinary Medical Association 65: 189-199.

Blood DC, Radostits OM (1989) Veterinary Medicine, 7th edn. Balliere and Tindal, London.

Cebra CK, Garry FB, Dinsmore RP (1996) Naturally occurring acute coliform mastitis in Holstein cattle. Journal of Veterinary Internal Medicine 10 : 252-257.

Chandrasekaran D, Kavitha S, Subapriya S, Nambi AP, Thirunavukkarasu PS, Vairamuthu S (2015) Haematobiochemical alterations of resistant mastitis in dairy cows. Indian Veterinary Journal $92: 11-13$.

Djabri B, Bareille N, Beaudeau F, Seegers H (2002) Quarter milk somatic cell count in infected dairy cows: a metaanalysis. Veterinary Research 33: 335-357.
Dwivedi HP, Kumar M, Upadhyay AK (2004) Biochemical changes in cows suffering from mastitis. Indian Journal of Veterinary Medicine 24 : 101-102.

Gargouri A, Hamed H, Elfeki A (2008) Total and differential bulk cow milk somatic cell counts and their relation with lipolysis. Livestock Science 113: 274-279.

Gibbons WJ, Catcott EJ, Smithcors JF (1970) Bovine Medicine and Surgery. 11th edition. American Veterinary Publication, Pp. 711.

Hussain R, Javed MT, Khan A, Ahmood F, Kausar R (2012) Mastitis and associated histo-pathological consequences in the context of udder morphology. International Journal of Agriculture Biology 14 : 947-952.

Hussain R, Khan A, Javed MT, Ali F (2013) Morphometric and pathological studies on mammary gland of slaughtered Nili-Ravi buffaloes. Pakistan Journal of Agricultural Sciences $50: 123-130$.

Khan MZ, Muhammad G, Umar A, Khan SA (1997) A preliminary comparison of plasma fibrinogen concentrations, leukocyte numbers and erythrocyte sedimentation rate as nonspecific indicators of inflammatory conditions in buffalo (Bubalis bubalis). Veterinary Research Communications 21: 265-271.

Rolands GJ, Booth JM (1988) Methods of data collection and analysis for cases of clinical bovine mastitis. In: Proceedings of the Society for Veterinary Epidemiology and Preventive Medicine, Pp. 116-125.

Schalm W, Carrol EJ, Jain NC (1971) Factors involved in infection and mastitis. In: Bovine mastitis. I Edn. Lee and Febiger, Philadelphia.

Siddiqe ZF, Islam S, Islam SS, Islam S, Islam S, Das BC (2015) Haematobiochemical changes in subclinical mastitis affected high yielding dairy cows in Chittagong district. International Journal of Natural and Social Sciences $2: 30-34$.

Singh H (1999) Electrolyte and mineral status in buffaloes at different stages of lactation and clinical mastitis. MVSc Thesis submitted to Punjab Agricultural University, Ludhiana, Punjab, India.

Singh R, Bhardwaj RK, Azad, MS, Beigh SA (2014) Effect of mastitis on haemato-biochemical and plasma mineral profile in crossbred cattle. Indian Journal of Animal Research 48 : 63-66.

Singh SV (2000) Udder health profiles with special reference to acute phase proteins and supplementation therapy. M.V.Sc thesis submitted to the GB Pant University of Agriculture and Technology, Pantnagar, India. 
Sischo WM, Moore DA, Fedon JC (1997) Use of physiological variables to predict milk yield after clinical mastitis in dairy cattle. Journal of the American Veterinary Medical Association 211: 470-475.

Sripad K, Upendra HA, Isloor S, Yathiraj S (2013) Prevalence of subclinical mastitis in organised farms in and around Bangalore. Frontier Journal of veterinary and animal sciences 2 :109-112.

Swarup D, Kumar PN, Singh R (1989) Electrical conductivity of milk for the detection of mastitis. Indian Journal of Animal Sciences 59: 1227-1229.

Wegner TN, Stull JW (1978) Relationship between mastitis test score, mineral composition of milk and blood electrolyte profiles in Holstein cows. Journal of Dairy Science 61: 17551759.

Yildiz H, Kaygusuzolu E (2005) Investigation of Ca, Zn, Mg, $\mathrm{Fe}$ and $\mathrm{Cu}$ concentrations in blood and milk of cows with negative and positive CMT results. Bulletin of the Veterinary Institute in Pulawy 49: 209-213.

Zaki MS, El-Battrawy N, Mostafa SO (2010) Some biochemical Studies on Friesian Suffering from Subclinical Mastitis. Nature and Science 8 : 143-146.

Zaki MS, Sharaf NE, Mostafa SO, Fawzi OM, El-Battrawy N (2008) Effect of subclinical mastitis on some biochemical and clinic-pathological parameters in buffalo. American-Eurasian Journal of Agricultural and Environmental Sciences 3 : 200204. 